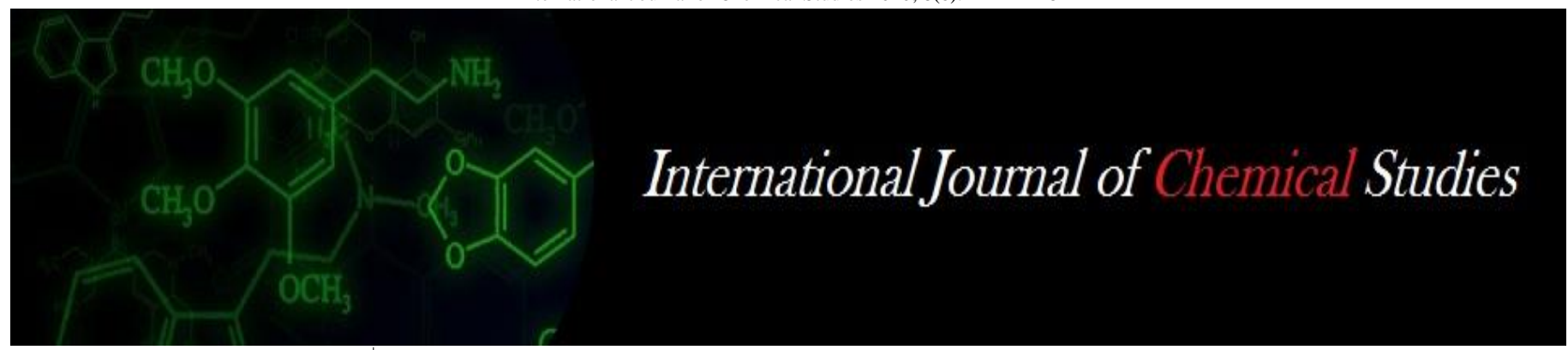

P-ISSN: 2349-8528

E-ISSN: 2321-4902

www.chemijournal.com

IJCS 2020; 8(6): 2244-2248

(C) 2020 IJCS

Received: 23-09-2020

Accepted: 26-11-2020

Sadhana R Babar

AICRP on Pearl millet, Regional

Agricultural Research Station,

Vijayapur, UAS, Dharwad,

Karnataka, India

\section{AK Guggari}

Regional Agricultural Research

Station, Vijayapur, UAS,

Dharwad, Karnataka, India

\section{BK Athoni}

AICRP on Pearl millet, Regional Agricultural Research Station,

Vijayapur, UAS, Dharwad,

Karnataka, India

Kumari Basamma

AICRP on Pearl millet, Regional

Agricultural Research Station,

Vijayapur, UAS, Dharwad,

Karnataka, India
Corresponding Author: Sadhana R Babar

AICRP on Pearl millet, Regional Agricultural Research Station,

Vijayapur, UAS, Dharwad,

Karnataka, India

\section{Influence of foliar application of iron on pearl millet growth, yield and economics under dryland condition}

\author{
Sadhana R Babar, AK Guggari, BK Athoni and Kumari Basamma
}

DOI: https://doi.org/10.22271/chemi.2020.v8.i6af.11109

\begin{abstract}
The present investigation was conducted at Regional Agricultural Research Station, Vijayapur during kharif 2015, 2016 and 2017 in medium black soil. The experiment was designed in a split plot design comprising three pearl millet hybrids as main plots (GHB-558, $86 \mathrm{M} 88$ and Kaveri super boss) and four levels of $\mathrm{FeSO}_{4}$ foliar application (control, $0.25 \%, 0.50 \%, 0.75 \%$ of $\mathrm{Fe}$ ) in sub plots. Kaveri super boss has recorded higher seed weight per plant $(27.28 \mathrm{~g})$, test weight $(12.74 \mathrm{~g})$, grain $\left(2335 \mathrm{~kg} \mathrm{ha}^{-1}\right)$, dry fodder $\left(4109 \mathrm{~kg} \mathrm{ha}^{-1}\right)$ yield and was on par with $86 \mathrm{M} \mathrm{88}$. Foliar application of $\mathrm{FeSO}_{4}$ at $0.75 \%$ has reported significantly higher grain $\left(2268 \mathrm{~kg} \mathrm{ha}^{-1}\right)$ and dry fodder yield compared to control. Interaction of Kaveri super boss with $0.75 \% \mathrm{FeSO}_{4}$ foliar application reported highest grain yield $\left(2491 \mathrm{~kg} \mathrm{ha}^{-1}\right)$, net returns (Rs. 19,169) and B:C ratio (2.45) and was on par with $86 \mathrm{M} 88+0.75 \% \mathrm{FeSO}_{4}$ foliar application.
\end{abstract}

Keywords: pearl millet, foliar application, iron sulphate, yield, economics

\section{Introduction}

Pearl millet [Pennisetum glaucum (L.)] is an important cereal crop of arid and semi-arid regions of India. It is popularly known as Bajra and being drought tolerant generally grown as rainfed crop on marginal lands under low input management conditions. Pearl millet grains are not only nutritionally comparable but are also superior to major cereals with respect to protein, energy, vitamins and minerals. Besides they are rich source of dietary fibre, phytochemicals, micronutrients, nutraceuticals and hence, now a days they are rightly termed as "nutricereal". It occupies an area of 6.93 million ha with an average production of 8.61 million tones and productivity of $1243 \mathrm{~kg} \mathrm{ha}^{-1}$ during 2018-19 (Anon., 2020) ${ }^{[2]}$. The major pearl millet growing states are Rajasthan, Maharashtra, Gujarat, Uttar Pradesh and Haryana which account for more than $90 \%$ of pearl millet acreage in the country. The main causes of low productivity are prevailing abiotic stresses like drought, poor soil fertility, high soil $\mathrm{pH}$ and high temperature. These factors limit the uptake of applied nutrients by roots and also do not able to turn over the nutrients commensurate with crop nutritional requirement at different growth stages.

Iron $(\mathrm{Fe})$ is an essential micronutrient for plants and for humans, and it is a constituent of a number of important macromolecules, including those involved in respiration, photosynthesis, chlorophyll synthesis, nitrogen fixation and metabolism (Kim and Rees, 1992) ${ }^{[7]}$. Plants obtain Fe from the soil, where Fe exists in either the ferrous $\left(\mathrm{Fe}^{2+}\right)$ or ferric $\left(\mathrm{Fe}^{3+}\right)$ ionic state. Although $\mathrm{Fe}$ is the fourth most abundant element in the earth's crust, it is poorly bioavailable in soil because it binds rapidly to soil particles and forms insoluble complexes under aerobic conditions at a neutral or alkaline $\mathrm{pH}$ (Gomez-Galera et al., 2010) ${ }^{[6]}$.

Agronomic biofortification is defined as the process of increasing the concentrations of essential elements in the edible portions of staple food plants through soil application, foliar application, by adding the elements to irrigation water (fertilization) or genetic improvement. This strategy was developed as a food based method to address widespread deficiencies in Fe and $\mathrm{Zn}$ that remain prevalent to the greatest extent in low income countries (Sadeghzadeh and Rengel, $2013^{[15]}$; Mao et al., $2014^{[10]}$ ).

Foliar spraying is a new method for crop feeding in which micronutrients in the form of liquid are used into leaves (Nasiri et al., 2010) ${ }^{[12]}$. Foliar application of micronutrient is more beneficial than soil application. 
Since, application rates are lesser as compared to soil application, same quantity of nutrient application could be supplied easily and crop reacts to nutrient application immediately. Foliar fertilizer sprays have proved to be a sustainable, effective and low cost strategy to improve Fe and $\mathrm{Zn}$ levels in edible portions of staple food crops (Ling et al., 2013) ${ }^{[9]}$. Foliar spraying of micronutrient is very helpful when the roots cannot provide necessary nutrients (Babaeian et al., 2011) ${ }^{[3]}$. Moreover, soil pollution would be a major problem by soil application of micronutrients. Narimani et al. (2010) ${ }^{[11]}$ reported that microelements foliar applications improve the effectiveness of macronutrients. Therefore, the aim of the experiment was to assess the effect of ferrous sulfate applications on Fe biofortification also to study its impacts on the yield and economics of pearl millet.

\section{Materials and Methods}

The field experiment was conducted during kharif 2015, 2016 and 2017 for three years at Regional Agricultural Research Station, Vijayapur situated in the Northern Dry Zone (Zone-3) of Agro-climatic region-II of Karnataka. The field is located at $16^{\circ} 49^{\prime} \mathrm{N}$ latitude and $75^{\circ} 43^{\prime} \mathrm{E}$ longitude and $593 \mathrm{~m}$ above mean sea level with annual rainfall ranging from 550 to 680 $\mathrm{mm}$. Soil of the experimental plot was clay loam in texture, alkaline in reaction $(\mathrm{pH} 8.1)$ with low organic carbon $(0.61 \%)$. The available soil $\mathrm{N}, \mathrm{P}$ and $\mathrm{K}$ were $184.00,18.2$ and $390.0 \mathrm{~kg} \mathrm{ha}^{-1}$, respectively (Table 1 ). The experiment was laid out in Split plot design with three main and four sub plot treatments replicated thrice. Each plot was $4 \mathrm{~m}$ in length and $3.6 \mathrm{~m}$ in width. There were twelve treatment combinations comprising three pearl millet hybrids i.e. M1: GHB-558, M2: 86 M 88, M3: Kaveri super boss and four levels of foliar application S1: control (No spray), S2: $0.25 \%$ of $\mathrm{FeSO}_{4}, \mathrm{~S} 3$ : $0.50 \%$ of $\mathrm{FeSO}_{4}, \mathrm{~S} 4: 0.75 \%$ of $\mathrm{FeSO}_{4}$. Iron sulphate was applied at 25 to 30 days after sowing (DAS). Urea and diammonium phosphate (DAP) were used as source of nitrogen and phosphorus. Fertilizers were applied based on the state recommendation i.e. 50:25:0 kg NPK ha ${ }^{-1}$ and $2.5 \mathrm{t}$ $\mathrm{ha}^{-1}$ of farm yard manure. After land preparation farm yard manure was applied and fertilizers were applied at the time of sowing. The seed rate used was $4 \mathrm{~kg} \mathrm{ha}^{-1}$ with plant geometry at $45 \times 15 \mathrm{~cm}$ in each experimental plot. Sowing was done plot wise, $45 \mathrm{~cm}$ marker was used for rows marking and seeds were placed manually by keeping the plant to plant spacing at $15 \mathrm{~cm}$.

Table 1: Initial properties of the soil samples of experimental field

\begin{tabular}{|c|c|c|c|c|c|c|c|c|c|c|c|c|}
\hline \multirow{2}{*}{ Soil Properties } & \multirow{2}{*}{ Texture } & \multirow{2}{*}{ pH } & \multirow{2}{*}{$\begin{array}{c}\mathbf{O M} \\
\left(\mathrm{g} \mathrm{kg}^{-1}\right)\end{array}$} & $\mathbf{C a}$ & $\mathrm{Mg}$ & $\mathbf{N}$ & $\mathbf{P}$ & $\mathbf{K}$ & $\mathbf{S}$ & $\mathbf{F e}$ & $\mathbf{Z n}$ & $\mathbf{C u}$ \\
\hline & & & & \multicolumn{2}{|c|}{ meq 100g-1 } & \multicolumn{4}{|c|}{$\left(\mathrm{kg} \mathrm{ha}^{-1}\right)$} & \multicolumn{3}{|c|}{$\left(\mathrm{mg} \mathrm{g}^{-1}\right)$} \\
\hline Result & Medium black soil & 8.1 & 0.61 & 5.8 & 0.7 & 184 & 18.2 & 390 & 22.7 & 10.9 & 0.89 & 0.43 \\
\hline Critical level & - & Alkaline & 0.5 & 2.0 & 0.5 & - & 10 & 120 & 10 & 4.0 & 0.6 & 0.2 \\
\hline
\end{tabular}

Five plants from each plot were sampled randomly for collection of different plant characters and yield attributes. Data on growth parameters like plant height $(\mathrm{cm})$, total and effective number of tillers plant ${ }^{-1}$, earhead length $(\mathrm{cm})$, earhead girth $(\mathrm{cm})$ and on yield contributing characters such as seed weight plant $^{-1}, 1000$ grain weight, grain and dry fodder yield $\left(\mathrm{kg} \mathrm{ha}^{-1}\right)$ were recorded. For seed weight per plant the earheads of sampled plants were threshed separately and grain weight recorded. The net plot and gross plots were harvested one by one, taking care that there will not be mixture. The produce of each net plot was threshed separately, cleaned and the grain yield was recorded in $\mathrm{kg}$ per net plot and then converted into $\mathrm{kg} \mathrm{ha}^{-1}$. Straw yield was obtained by subtracting the grain yield of each net plot from their respective total dry matter (above ground) yield and computed in terms of $\mathrm{kg} \mathrm{ha}^{-1}$ and converted it on hectare basis. Experimental data recorded was statistically analyzed with the help of statistical package MSTAT-C.

Weather data during the crop growth period average for last ten years (2008 to 2017) is presented in Fig 1. The average rainfall of growing period i.e. from July to October was 421 $\mathrm{mm}$ (average of 10 years, 2008 to 2017) and the rainfall received during growing period (July to October) was 428.9, 363.1, 572.1 $\mathrm{mm}$ in the year 2015, 2016 and 2017, respectively. The rainfall received during July, August and first week of September is useful for the crop growth. The mean weekly minimum and maximum temperature during the crop season fluctuated from 19.9 to $30.8{ }^{\circ} \mathrm{C}$ with average relative humidity from 36.3 to $86.9 \%$. One or two irrigations with sprinkler were applied during the dry spells at early stage of crop establishment.

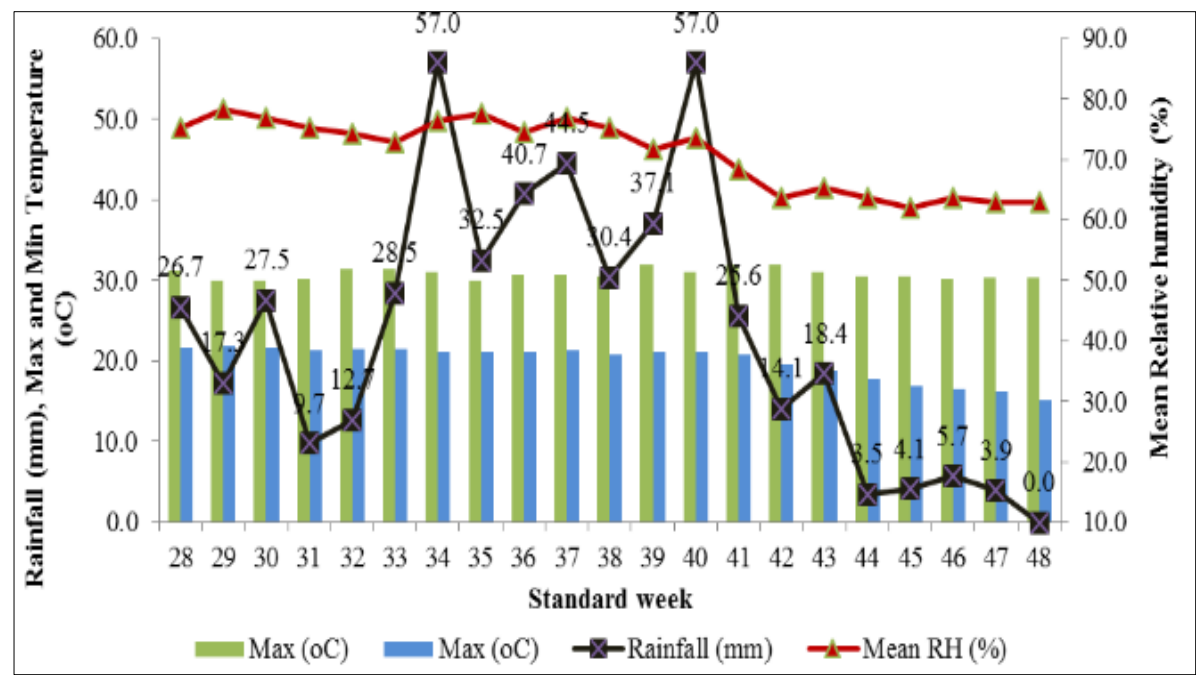

Fig 1: Rainfall, maximum and minimum temperature, mean relative humidity during the crop growth period (average of ten years 2008-2017) 


\section{Results and Discussion \\ Growth parameters}

Among the main plot treatments, pearl millet hybrid Kaveri super boss has recorded statistically higher plant height, ear head length and ear head girth $(173.8,23.57$ and $3.02 \mathrm{~cm}$, respectively) than GHB 558 and it was on par with $86 \mathrm{M} 88$ (157.3, 22.77 and $3.00 \mathrm{~cm}$, respectively) and $86 \mathrm{M} 88$ was superior in number of effective tillers per plant (3.01) (Table 2). Foliar application of $0.75 \%$ and $0.50 \% \mathrm{FeSO}_{4}$ at $25-30$ DAS have recorded statistically higher plant height, no of effective tillers per plant, ear head length and girth compared to control and $0.25 \%$ foliar application of $\mathrm{FeSO}_{4}$ and were on par with each other. Among the interaction, combination of pearl millet hybrid Kaveri super boss with $0.75 \% \mathrm{FeSO}_{4}$ spray has recorded higher plant height, ear lead length and girth (175.0, 24.0 and $3.10 \mathrm{~cm}$, respectively). In Vijayapur, the crop will experience moisture stress condition during vegetative growth stage due to lesser rainfall. Foliar application of $\mathrm{FeSO}_{4}$ increased the foliar nutrition and resistance to moisture stress condition, increased photosynthetic capacity and hence recorded higher growth. Similar results were reported by Cakmak et al. (2010) ${ }^{[4]}$ under micronutrients deficiency conditions, antioxidant enzyme activities decrease and thus increases the sensitivity of plants to environmental stresses. Akbari et al. (2013) ${ }^{[1]}$ reported that iron and zinc element in stress condition have an enhancing role on osmotic adjustment process (due to the increase of soluble carbohydrates). Under drought stress conditions the role of these elements can be seen as a contributor to osmotic regulation that with intervention in the synthesis of osmotic compounds for compatibility with stress and maintain turgor pressure performed their roles.

\section{Yield attributes and yield}

Kaveri super boss has recorded statistically higher seed weight per plant (27.28 g), test weight (12.74 g), grain (2335 $\mathrm{kg} \mathrm{ha}^{-1}$ ) and dry fodder (4109 $\mathrm{kg} \mathrm{ha}^{-1}$ ) yield, it was on par with $86 \mathrm{M} 88$ (27.08 g, $12.02 \mathrm{~g}, 2235$ and $3461 \mathrm{~kg} \mathrm{ha}^{-1}$, respectively). GHB 558 was poor in grain and dry fodder yield compared to these hybrids (1699 and $2558 \mathrm{~kg} \mathrm{ha}^{-1}$, respectively) (Table 3 ). The higher grain yield of pearl millet seemed to be the cumulative effect of yield attribute which was booted by balanced nutrients supply. Likewise, fodder yield was also increased significantly due to significant response of plant growth viz., plant height and number of tillers per plant. The findings are supported by those of Kumar et al., $2009^{[8]}$ and Patil et al., $2014^{[14]}$.

Foliar application of $\mathrm{FeSO}_{4}$ at 0.75 (2268 and $3503 \mathrm{~kg} \mathrm{ha}^{-1}$ ) and $0.50 \%$ (2120 and $3480 \mathrm{~kg} \mathrm{ha}^{-1}$ ) has resulted in higher grain and dry fodder yield, respectively. Plot without any foliar application has recorded lesser grain and fodder yield (1890 and $3111 \mathrm{~kg} \mathrm{ha}^{-1}$, respectively). Treatment combination of Kaveri super boss with $0.75 \% \mathrm{FeSO}_{4}$ foliar application was superior in grain yield $\left(2491 \mathrm{~kg} \mathrm{ha}^{-1}\right)$ and was on par with hybrid $86 \mathrm{M} 88$ with $0.75 \% \mathrm{FeSO}_{4}$ foliar application $(2489 \mathrm{~kg}$ $\left.\mathrm{ha}^{-1}\right)$. Foliar nutrition with micronutrient Fe enhances the early vigour and thus helps in better growth by increasing the uptake of other nutrients, increased the photosynthesis rate, physiological and metabolic processes of the plant followed by increased translocation toward yield contributing characters. The experimental results reported by Odeley and Animashaun (2007) ${ }^{[13]}$ showed that foliar application of micronutrients increased the soybean yield, quality, resistance to pests and diseases and drought stress. Fulpagare et al. in $2018^{[5]}$ concluded that consumption of iron and zinc fertilizer considerably improved yield and yield components of pearl millet on vertisol.

\section{Economics}

Pearl millet hybrid Kaveri super boss (Rs.30,355 ha-1, 17,274 $\mathrm{ha}^{-1}$ and 2.32, respectively) and $86 \mathrm{M} 88$ (Rs. 29,052 ha-1, $15,670 \mathrm{ha}^{-1}$ and 2.17 , respectively) have recorded higher gross returns, net returns and $\mathrm{B}: \mathrm{C}$ ratio compared to GHB 558 (Rs. $22,090 \mathrm{ha}^{-1}$, 9,909 $\mathrm{ha}^{-1}$ and 1.81 , respectively). Foliar allocation of $\mathrm{FeSO}_{4}$ at 0.75 and $0.50 \%$ has recorded higher gross returns, net returns and $\mathrm{B}: \mathrm{C}$ ratio compared to control and $0.25 \%$ foliar application of $\mathrm{FeSO}_{4}$ (Table 4). Interaction effect of hybrid Kaveri supper boss with foliar allocation of $\mathrm{FeSO}_{4}$ at $0.75 \%$ has recorded highest gross (Rs. 32,381 ha-1), net returns (Rs. 19,169 ha-1) and B:C ratio (2.45) compared to other treatments. Higher yield recorded in this interaction combination has resulted in higher gross returns and $\mathrm{B}: \mathrm{C}$ ration. The treatment comprising of pearl millet hybrid GHB 558 with no foliar application with $\mathrm{FeSO}_{4}$ has recorded lowest gross returns (Rs. 20,723 ha-1), net returns (Rs. 8,673 ha- ${ }^{-1}$ ) and $\mathrm{B}: \mathrm{C}$ ratio (1.72).

\section{Conclusion}

The present investigation showed that, application of $0.75 \%$ $\mathrm{FeSO}_{4}$ as foliar spray at 25-30 days after sowing in pearl millet under dryland condition is useful in achieving higher grain yield, dry fodder yield, net retunes and B:C ration. Foliar application as being a low cost technology it gives higher returns to the cultivator. Hence, foliar feeding can be accepted an effective way to compensate soil deficiency and inability of soil to transfer nutrients to the plants to maintain high productivity of dryland crops.

Table 2: Plant height, total and effective no of tillers plant ${ }^{-1}$, ear head length and girth as influenced by the genotypes and levels of $\mathrm{FeSO}_{4}$ application (Pooled mean of 3 years)

\begin{tabular}{|c|c|c|c|c|c|}
\hline Treatment details & Plant height $(\mathbf{c m})$ & $\begin{array}{c}\text { Total number of } \\
\text { tillers plant } \\
\end{array}$ & \begin{tabular}{|c} 
No of effective tillers \\
plant $^{-1}$
\end{tabular} & \begin{tabular}{|c|}
$\begin{array}{c}\text { Ear head length } \\
(\mathrm{cm})\end{array}$ \\
\end{tabular} & $\begin{array}{c}\text { Ear head girth } \\
(\mathrm{cm})\end{array}$ \\
\hline \multicolumn{6}{|c|}{ Main plot treatments (M) } \\
\hline M1: GHB-558 & 126.9 & 4.41 & 2.91 & 19.20 & 2.79 \\
\hline $\mathrm{M}_{2}: 86 \mathrm{M} 88$ & 157.3 & 4.47 & 3.01 & 22.77 & 3.00 \\
\hline $\mathrm{M}_{3}$ : Kaveri super boss & 173.8 & 4.27 & 2.83 & 23.57 & 3.02 \\
\hline S.Em \pm & 2.40 & 0.06 & 0.06 & 0.32 & 0.03 \\
\hline C.D. $(0.05)$ & 9.44 & 0.24 & 0.23 & 1.24 & 0.11 \\
\hline \multicolumn{6}{|c|}{ Sub plot treatments (S) } \\
\hline $\mathrm{S}_{1}$ : Control & 150.6 & 4.21 & 2.66 & 21.39 & 2.88 \\
\hline $\mathrm{S}_{2}: 0.25 \%$ at tillering/jointing stage & 152.2 & 4.47 & 2.93 & 21.62 & 2.92 \\
\hline $\mathrm{S}_{3}: 0.50 \%$ at tillering/jointing stage & 154.5 & 4.42 & 3.09 & 22.17 & 2.97 \\
\hline $\mathrm{S}_{4}: 0.75 \%$ at tillering/jointing stage & 153.3 & 4.41 & 2.99 & 22.22 & 2.97 \\
\hline S.Em \pm & 2.75 & 0.07 & 0.07 & 0.29 & 0.03 \\
\hline
\end{tabular}




\begin{tabular}{|c|c|c|c|c|c|}
\hline C.D.(0.05) & 8.16 & 0.22 & 0.20 & 0.87 & 0.10 \\
\hline \multicolumn{4}{|c|}{ Interaction (M X S) } & & \\
\hline $\mathrm{M}_{1} \mathrm{~S}_{1}$ & 125.0 & 4.24 & 2.62 & 18.97 & 2.75 \\
\hline $\mathrm{M}_{1} \mathrm{~S}_{2}$ & 125.3 & 4.56 & 2.96 & 18.99 & 2.78 \\
\hline $\mathrm{M}_{1} \mathrm{~S}_{3}$ & 129.9 & 4.36 & 3.07 & 19.30 & 2.81 \\
\hline $\mathrm{M}_{1} \mathrm{~S}_{4}$ & 127.2 & 4.49 & 3.00 & 19.54 & 2.80 \\
\hline $\mathrm{M}_{2} \mathrm{~S}_{1}$ & 154.2 & 4.29 & 2.76 & 21.82 & 2.94 \\
\hline $\mathrm{M}_{2} \mathrm{~S}_{2}$ & 159.0 & 4.62 & 3.02 & 22.88 & 3.02 \\
\hline $\mathrm{M}_{2} \mathrm{~S}_{3}$ & 158.2 & 4.62 & 3.27 & 23.27 & 3.05 \\
\hline $\mathrm{M}_{2} \mathrm{~S}_{4}$ & 157.6 & 4.33 & 2.98 & 23.12 & 3.00 \\
\hline $\mathrm{M}_{3} \mathrm{~S}_{1}$ & 172.5 & 4.11 & 2.60 & 23.39 & 2.94 \\
\hline $\mathrm{M}_{3} \mathrm{~S}_{2}$ & 172.3 & 4.24 & 2.80 & 22.98 & 2.97 \\
\hline $\mathrm{M}_{3} \mathrm{~S}_{3}$ & 175.4 & 4.29 & 2.93 & 23.92 & 3.06 \\
\hline $\mathrm{M}_{3} \mathrm{~S}_{4}$ & 175.0 & 4.42 & 3.00 & 24.00 & 3.10 \\
\hline S.Em \pm & 4.76 & 0.13 & 0.11 & 0.51 & 0.06 \\
\hline C.D.(0.05) & 14.14 & 0.38 & 0.34 & 1.50 & 0.17 \\
\hline
\end{tabular}

Table 3: Effect of the different genotypes and levels of $\mathrm{FeSO}_{4}$ application on seed weight per plant, test weight, grain and dry fodder yield (Pooled mean of 3 years)

\begin{tabular}{|c|c|c|c|c|}
\hline Treatment details & Seed weight plant ${ }^{-1}(g)$ & Test weight $(\mathrm{g})$ & Grain yield (kg ha-1) & Dry fodder yield (kg ha-1) \\
\hline \multicolumn{5}{|c|}{ Main plot treatments (M) } \\
\hline $\mathrm{M}_{1}: \mathrm{GHB}-558$ & 19.75 & 10.85 & 1699 & 2558 \\
\hline $\mathrm{M}_{2}: 86 \mathrm{M} 88$ & 27.08 & 12.02 & 2235 & 3461 \\
\hline $\mathrm{M}_{3}$ : Kaveri super boss & 27.28 & 12.74 & 2335 & 4109 \\
\hline S.Em \pm & 0.43 & 0.29 & 35.90 & 56.61 \\
\hline C.D.(0.05) & 1.70 & 0.91 & 140.97 & 222.26 \\
\hline \multicolumn{5}{|c|}{ Sub plot treatments $(\mathrm{S})$} \\
\hline $\mathrm{S}_{1}$ : Control & 23.17 & 11.18 & 1890 & 3111 \\
\hline $\mathrm{S}_{2}: 0.25 \%$ at tillering/jointing stage & 23.95 & 11.41 & 2081 & 3410 \\
\hline $\mathrm{S}_{3}: 0.50 \%$ at tillering/jointing stage & 25.54 & 12.37 & 2120 & 3480 \\
\hline $\mathrm{S}_{4}: 0.75 \%$ at tillering/jointing stage & 26.15 & 12.52 & 2268 & 3503 \\
\hline S.Em \pm & 0.57 & 0.31 & 49.40 & 73.39 \\
\hline C.D.(0.05) & 1.72 & 0.94 & 146.77 & 218.05 \\
\hline \multicolumn{5}{|c|}{ Interaction (M X S) } \\
\hline $\mathrm{M}_{1} \mathrm{~S}_{1}$ & 18.39 & 10.28 & 1594 & 2280 \\
\hline $\mathrm{M}_{1} \mathrm{~S}_{2}$ & 19.27 & 10.67 & 1744 & 2703 \\
\hline $\mathrm{M}_{1} \mathrm{~S}_{3}$ & 20.29 & 11.13 & 1635 & 2616 \\
\hline $\mathrm{M}_{1} \mathrm{~S}_{4}$ & 21.05 & 11.32 & 1824 & 2634 \\
\hline $\mathrm{M}_{2} \mathrm{~S}_{1}$ & 25.52 & 11.07 & 1994 & 3229 \\
\hline $\mathrm{M}_{2} \mathrm{~S}_{2}$ & 26.31 & 11.25 & 2169 & 3490 \\
\hline $\mathrm{M}_{2} \mathrm{~S}_{3}$ & 28.02 & 12.76 & 2288 & 3509 \\
\hline $\mathrm{M}_{2} \mathrm{~S}_{4}$ & 28.48 & 13.01 & 2489 & 3616 \\
\hline $\mathrm{M}_{3} \mathrm{~S}_{1}$ & 25.61 & 12.18 & 2083 & 3823 \\
\hline $\mathrm{M}_{3} \mathrm{~S}_{2}$ & 26.28 & 12.32 & 2328 & 4038 \\
\hline $\mathrm{M}_{3} \mathrm{~S}_{3}$ & 28.30 & 13.21 & 2438 & 4315 \\
\hline $\mathrm{M}_{3} \mathrm{~S}_{4}$ & 28.91 & 13.24 & 2491 & 4258 \\
\hline S.Em \pm & 0.66 & 0.34 & 45.56 & 67.11 \\
\hline C.D. $(0.05)$ & 1.95 & 1.09 & 134.22 & 197.67 \\
\hline
\end{tabular}

Table 4: Effect of different genotypes and levels of $\mathrm{FeSO}_{4}$ application on economics of pearl millet (Pooled mean of 3 years)

\begin{tabular}{|c|c|c|c|c|}
\hline Treatment details & Cost of cultivation (Rs. ha' ha $^{-1}$ & Gross returns (Rs. ha' $\left.{ }^{-1}\right)$ & Net returns (Rs. ha-1) & B:C ratio \\
\hline \multicolumn{5}{|c|}{ Main plot treatments $(\mathrm{M})$} \\
\hline $\mathrm{M}_{1}: \mathrm{GHB}-558$ & 12,181 & 22,090 & 9,909 & 1.81 \\
\hline $\mathrm{M}_{2}: 86 \mathrm{M} 88$ & 13,381 & 29,052 & 15,670 & 2.17 \\
\hline $\mathrm{M}_{3}$ : Kaveri super boss & 13,081 & 30,355 & 17,274 & 2.32 \\
\hline S.Em \pm & - & 361.4 & 361.4 & 0.04 \\
\hline C.D. $(0.05)$ & - & 1101.6 & 1101.6 & 0.15 \\
\hline \multicolumn{5}{|c|}{ Sub plot treatments $(\mathrm{S})$} \\
\hline $\mathrm{S}_{1}$ : Control & 12,750 & 24,574 & 11,824 & 1.92 \\
\hline $\mathrm{S}_{2}: 0.25 \%$ at tillering/jointing stage & 12,838 & 27,047 & 14,209 & 2.10 \\
\hline $\mathrm{S}_{3}: 0.50 \%$ at tillering/jointing stage & 12,925 & 27,561 & 14,636 & 2.12 \\
\hline $\mathrm{S}_{4}: 0.75 \%$ at tillering/jointing stage & 13,013 & 29,480 & 16,467 & 2.26 \\
\hline S.Em \pm & - & 442.3 & 442.3 & 0.05 \\
\hline C.D.(0.05) & - & 1398.0 & 1398.0 & 0.15 \\
\hline \multicolumn{5}{|c|}{ Interaction (M X S) } \\
\hline $\mathrm{M}_{1} \mathrm{~S}_{1}$ & 12,050 & 20,723 & 8,673 & 1.72 \\
\hline $\mathrm{M}_{1} \mathrm{~S}_{2}$ & 12,138 & 22,675 & 10,537 & 1.87 \\
\hline $\mathrm{M}_{1} \mathrm{~S}_{3}$ & 12,225 & 21,255 & 9,030 & 1.74 \\
\hline
\end{tabular}




\begin{tabular}{|c|c|c|c|c|}
\hline $\mathrm{M}_{1} \mathrm{~S}_{4}$ & 12,313 & 23,708 & 11,395 & 1.93 \\
\hline $\mathrm{M}_{2} \mathrm{~S}_{1}$ & 13,250 & 25,920 & 12,670 & 1.96 \\
\hline $\mathrm{M}_{2} \mathrm{~S}_{2}$ & 13,338 & 28,198 & 14,860 & 2.11 \\
\hline $\mathrm{M}_{2} \mathrm{~S}_{3}$ & 13,425 & 29,739 & 16,314 & 2.22 \\
\hline $\mathrm{M}_{2} \mathrm{~S}_{4}$ & 13,513 & 32,351 & 18,838 & 2.39 \\
\hline $\mathrm{M}_{3} \mathrm{~S}_{1}$ & 12,950 & 27,080 & 14,130 & 2.09 \\
\hline $\mathrm{M}_{3} \mathrm{~S}_{2}$ & 13,038 & 30,270 & 17,232 & 2.32 \\
\hline $\mathrm{M}_{3} \mathrm{~S}_{3}$ & 13,125 & 31,690 & 18,565 & 2.41 \\
\hline $\mathrm{M}_{3} \mathrm{~S}_{4}$ & 13,213 & 32,381 & 19,169 & 2.45 \\
\hline S.Em \pm & - & 412.3 & 412.3 & 0.09 \\
\hline C.D.(0.05) & - & 1314.8 & 1314.8 & 0.26 \\
\hline
\end{tabular}

\section{Acknowledgments}

This study was financed by the All India Coordinated Research Project on Pearl millet, Jodhpur, Rajasthan, India.

\section{References}

1. Akbari OS, Chen $\mathrm{CH}$, Marshall JM, Huang $\mathrm{H}$, Antoshechkin I. A synthetic gene drive system for local, reversible modification and suppression of insect populations. Current Biology 2013;23:671-677.

2. Anonymous. Project Coordinator Review. All India Coordinated Research Project on Pearl millet, Jodhpur, India 2020, 1.

3. Babaeian MI, Piri A, Tavassoli Y, Esmaeilian H, Gholami. Effect of water stress and micronutrients (Fe, $\mathrm{Zn}$ and $\mathrm{Mn}$ ) on chlorophyll fluorescence, leaf chlorophyll content and sunflower nutrient uptake in Sistan region. African Journal of Agriculture Research 2011;6(15):3526-3531.

4. Cakmak I, Pfeiffer WH, McClafferty B. Biofortification of durum wheat with zinc and iron. Cereal Chemistry 2010;87:10-20.

5. Fulpagare DD, Patil TD, Ritu Thakare S. Effect of application of iron and zinc on nutrient availability and pearl millet yield in vertisols. International Journal of Chemical Studies 2018;6(6):2647-2650.

6. Gomez-Galera S, Rojas E, Sudhakar D, Zhu C, Pelacho A, Capell $\mathrm{T}$ et al. Critical evaluation of strategies for mineral fortification of staple food crops. Transgenic Research 2010;19:165-180.

7. Kim J, Rees DC. Structural models for the metal centers in the nitrogenous molybdenum-iron protein. Science 1992;257:1677-1682.

8. Kumar P, Yadav SK, Kumar S, Kumar M. Sustaining yield of pearl millet-wheat cropping system in semi-arid conditions. Haryana Journal of Agronomy 2009;25(1\&2):1-3.

9. Ling $\mathrm{Y}, \mathrm{Wu} \mathrm{L}$, Yanga $\mathrm{C}$, Lva Q. Effects of iron and zinc foliar applications on rice plants and their grain accumulation and grain nutritional quality. Journal of the Science of Food and Agriculture 2013;93:254-261.

10. Mao H, Wang J, Wang Z, Zan Y, Lyons G, Zou C. Using agronomic biofortification to boost zinc, selenium, and iodine concentrations of food crops grown on the loess plateau in China. Journal of Soil Science and Plant Nutrition 2014;14:459-470.

11. Narimani H, Rahimi MM, Ahmadikhah A, Vaezi B. Study on the effects of foliar spray of micronutrient on yield and yield components of durum wheat. Archives of Applied Science Reseasrch 2010;2(6):168-176.

12. Nasiri Y, Zehtab-Salmasi S, Nasrullahzadeh S, Najafi N, Ghassemi Golezani K. Effects of foliar application of micronutrients (Fe and $\mathrm{Zn}$ ) on flower yield and essential oil of chamomile (Matricaria chamomilla L.). Journal of Medicinal Plant Research 2010;4(17):1733-1737.
13. Odeley F, Animashaun MO. Effects of nutrient foliar spray on soybean growth and yield (Glycine max L.) in South West Nigeria. Australian Journal of Crop Science 2007;41:1842-1850.

14. Patil TD, Kolambe BN, Patil RG, Bafana AM. Effect of rates of castor cake and banana pseuedostem sap on yield and yield attributing character of organically grown garlic (Allium Sativum L.). Bioinfolet 2014;11(1A):100-104.

15. Sadeghzadeh B, Rengel Z. A review of zinc nutrition and plant breeding. Journal of Soil Science and Plant Nutrition 2013;13:905-927. 